\title{
Donkey Bite Leading to a Catastrophic Outcome: Bilateral Visual Loss
}

\author{
Mansooreh Jamshidian Tehrani, ${ }^{1}$ Shahbaz Nekoozadeh, ${ }^{1}$ Mohammad Soleimani, ${ }^{1}$ Seyed Ali \\ Tabatabaei, ${ }^{1, *}$ and Bahram Eshraghi ${ }^{1}$ \\ ${ }^{1}$ Ophtalmic Plastic and Reconstructive Surgery Unit, Eye Research Center, Farabi Eye Hospital, Tehran University of Medical Sciences, Tehran, IR Iran \\ "Corresponding author: Seyed Ali Tabatabaei, Ophtalmic Plastic and Reconstructive Surgery Unit, Eye Research Center, Farabi Eye Hospital, Tehran University of Medical \\ Sciences, Tehran, IR Iran. Tel: +98-9121096496, E-mail: alitabatabaei77@yahoo.com
}

Received 2016 February 16; Revised 2016 July 23; Accepted 2016 September 05.

\begin{abstract}
In this report we present a case of severe facial injury due to a donkey bite. Immediate repair with surgical flaps was performed. No significant complication was observed at the time of surgery or during follow up and the result was acceptable. Animal bites are relatively frequent and most often are done by dogs. Besides dogs, other animals such as cats, horses and donkeys may be responsible for this type of injuries. Although donkey bites to the facial area are very rare, they can cause severe and life-threatening injuries. Early management of facial injuries caused by animal bites is acceptable nowadays and guarantees satisfactory outcome.
\end{abstract}

Keywords: Donkey Bite, Facial Laceration, Primary Repair

\section{Introduction}

Animal bites to the face and periocular region are relatively frequent and have an important position in traumatology because of high complication rate compared to other types of injuries. Ten percent of soft tissue injuries to the orofacial region occur following mammalian bite (1). In spite of dog bites as the most common cause of injury (2), cows, camels, donkeys and horses may be responsible for this type of injury (3). Considering large variety of animal bites, reports about donkey bites to the face are very rare (3). However, it can cause severe facial disfigurement and large functional and cosmetic consequences. We report a rare case of bilateral globe rupture and severe facial injury due to a donkey bite, as our search showed there was no similar case report in the literature. This report alerts us to take precautious measurements when dealing with these animals.

\section{Case Presentation}

A 76-year-old male referred to the emergency department four hours after a severe donkey bite on his face. The patient was admitted, considering possibility of concomitant trauma, and ear, nose and throat (ENT) and neurosurgery consults were ordered. The patient received antibiotic, tetanus and Rabies prophylaxis.

The patient was taken to the operating room, where extensive loss of lateral canthus and lateral part of lower lid tissue of the right eye was found. Right lower eyelid was totally avulsed and it was only loosely connected to the subcutaneous tissue. In the left eye, superior and inferior lid margin laceration with extension to the upper and lower lids was observed. There was bi-canalicular laceration in both eyes. There was also a penetrating injury with full-thickness laceration in the left eye. Right eye was completely lost and disorganized. His vision was no light perception (NLP) in both eyes.

\subsection{Surgical Technique}

Under general anesthesia, left globe laceration was repaired. Investigation of the right eye showed the globe content was eviscerated by animal bite so only repair of retained tissue and conjunctiva was performed and conformer was inserted to save fornices. After copious irrigation of lid laceration, lid margin and levator laceration were primarily repaired for the left eye. Large tissue defect was observed on the right side, so nasojugal and rotational cheek flaps were used to cover the site of defect. Lid and levator laceration were then repaired (Figure 2). Because of anatomical disfigurement and extensive tissue contusion, investigation by an operating microscope to find canalicular laceration was unsuccessful and the lumen of lacrimal canaliculi was not visible.

\section{Discussion}

Animal bites account for hundreds of emergency department visits all over the world. It has been estimated that one to two million of the American population are bitten each year (4). Animal bites can range from simple scratching to life threatening head and neck injuries. The 


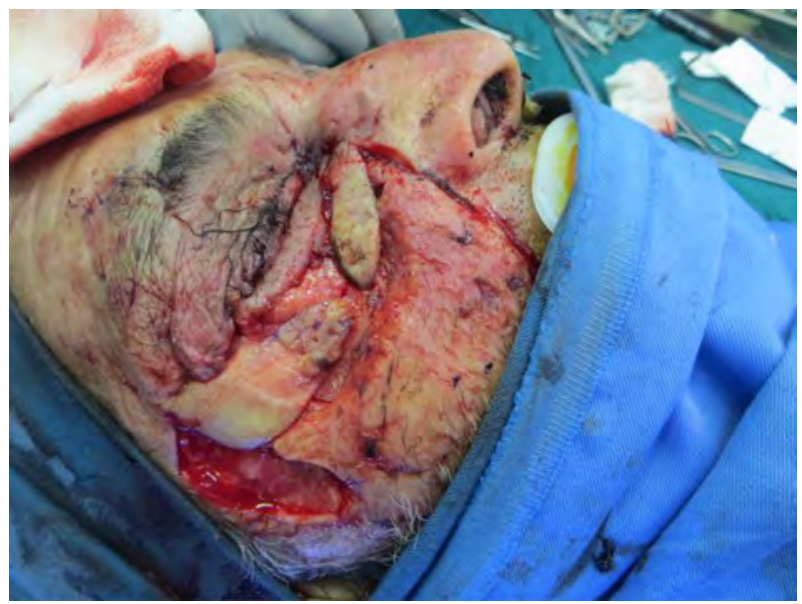

Figure 1. Preoperative View a Few Hours After Trauma

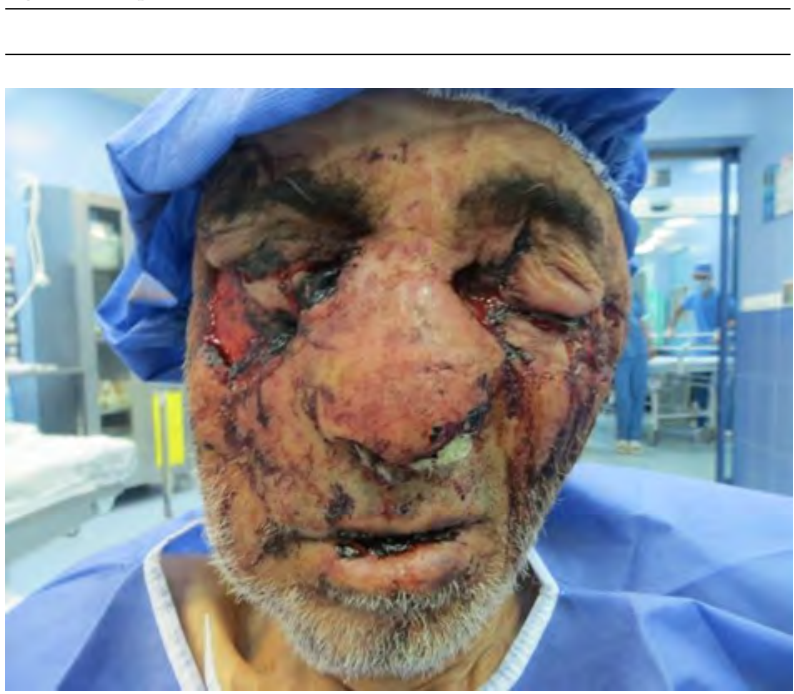

Figure 2. Intraoperative View of Elevating Flaps

most common sites of injury in the face are nose and ears. The incidence of human, cat and dog injuries is increasing these days but injuries due to donkey bites; especially in the face area is extremely uncommon (5). There are reports in the literature of facial injuries due to human or dog bite $(6,7)$, and a report of nasal amputation due to donkey bite (8) yet we could not find any report on donkey bite with bilateral globe rupture.

Even in the presence of severe facial and periorbital injuries caused by animal bites, intraocular trauma is exceedingly rare (9). Occasionally, however the globe is involved. There are reports about globe rupture after animal bites but it is usually accompanied by damage to orbital contents such as lacrimal gland, medial rectus muscle and trochlear nerve while penetrating injury itself is rare

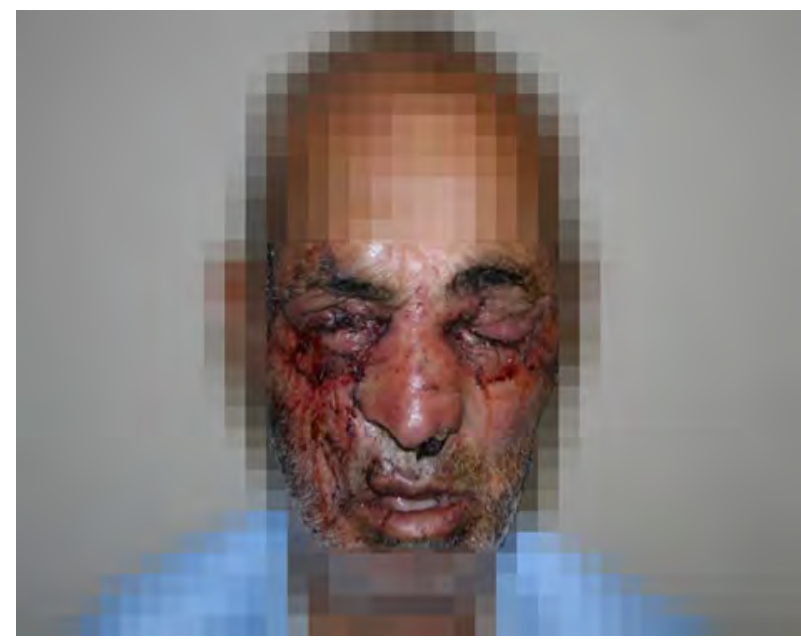

Figure 3. Postoperative View One Day After Surgery

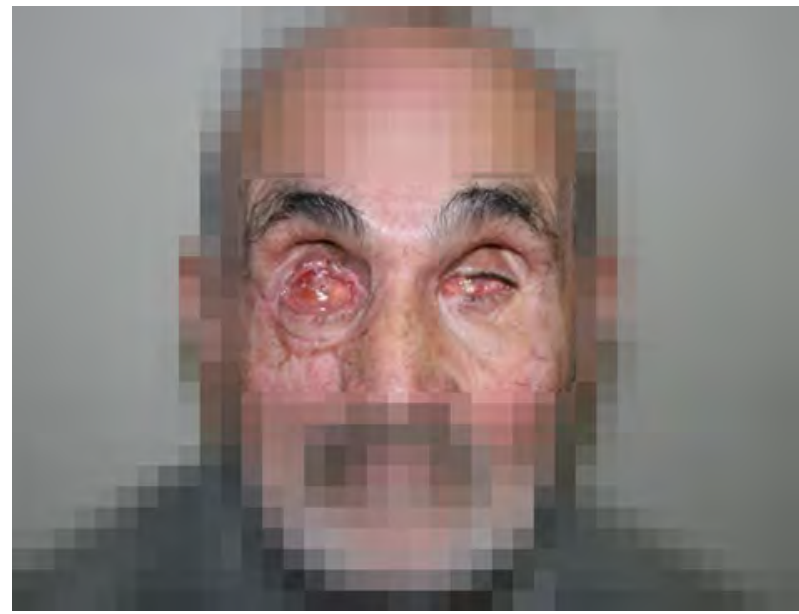

Figure 4. Postoperative View Five Months After Trauma

(10-12). Many globe lacerations occur after dog bites (13). Depending on numerous factors such as time of presentation and extension of ocular damage, visual outcomes vary greatly but many patients achieve some degree of visual improvement (10-13). In our case, despite all efforts to save the eyes, two eyes were lost. To the best of our knowledge, this is the first report of bilateral visual loss after animal bite.

Facial injuries can be severe and require reconstruction and complex repair. At the present time, primary closure of the wound whenever possible is acceptable. Copious irrigation, local wound cleansing, and excision of necrotic tissue should be considered before primary repair (12). In comparison with other tissues, blood supply of fa- 
cial tissues is superior and primary closure has little risk of infection (14). Avulsive injuries accompanied with significant tissue loss are difficult to manage and require autologous grafts and various local or regional flaps $(15,16)$.

Choosing the best technique for reconstructive procedure depends on the size of the defect, location, relationship to adjacent structures, available donor tissue and etc. In lower eye lid, several forms of flaps including full thickness, tarsoconjunctival and combined with the upper lid can be applied to cover large defects. Medial pedicle rotation flap of the cheek is an appropriate flap that can be used without great difficulties and its results are superior to temporal pedicle cheek flap or the frontal flap (17). Local flaps such as Rhomboid transposition flap, advancement flap; rotation-advancement flap (Mustarde flap) and v-y advancement (kite flap) are options in cheek reconstruction (18). Depending on skin color, skin thickness, tissue composition, location, and subunits involved, a full-thickness or partial-thickness skin graft can be applied. Choosing between multiple options depends on the creativity of surgeons as well as complete analysis of the defect. In one study that compared complications, patient satisfaction, tissue co-ordination, skin color and hospitalization days between local flap and skin graft to reconstruct cheek defects, 20 patients were treated using local flap and 20 with skin graft. After 12 months of follow up, results showed local flaps had better results regarding clinical outcomes and patient satisfaction (19).

In our case we used rotational cheek flaps to reconstruct the lower eye lid and cover tissue defects. Three months after surgery, outcome was satisfactory and the patient recovered with no significant complication. Only lid retraction was obvious in the right eye that may require fornix reconstruction to reach optimal outcome.

\section{References}

1. Ullah F, Tahir M, Aslam M. Mammalian bite injuries to the head and neck region. J Coll Physicians Surg Pak. 2005;15(8):485-8. [PubMed: 16202360].

2. Bernardo LM, Gardner MJ, Rosenfield RL, Cohen B, Pitetti R. A comparison of dog bite injuries in younger and older children treated in a pediatric emergency department. Pediatr Emerg Care. 2002;18:247-9. doi: 10.1097/00006565-200206000-00024.

3. Ugboko VI, Olasoji HO, Ajike SO, Amole AOD, Ogundipe OT. Facial injuries caused by animals in northern Nigeria. BrJ Oral Maxillofac Surg. 2002;40(5):433-7. doi: 10.1016/S026643560200181X.

4. Lewis KT, Stiles M. Management of cat and dog bites. Am Fam Physician. 1995;52(2):479-85. [PubMed: 7625323] 489-90.

5. Osterlund A, Nordlund E. Wound infection caused by Staphylococcus hyicus subspecies hyicus after a donkey bite. Scand J Infect Dis. 1997;29(1):95. [PubMed: 9112308].

6. Hussain G, Thomson S, Zielinski V. Nasal amputation due to human bite: microsurgical replantation. Aust N Z J Surg. 1997;67(6):382-4. [PubMed: 9193275].

7. Tajima S, Ueda K, Tanaka Y. Successful replantation of a bitten-off nose by microvascular anastomosis. Microsurgery. 1989;10(1):5-7. [PubMed: 2725256].

8. Christo D. Nasal amputation due to donkey bite: immediate and late reconstruction with a forehead flap. Shipkov Injury Extra. 2004;35:8590. doi: 10.1016/j.injury.2004.06.011.

9. Gonnering RS. Ocular adnexal injury and complications in orbital dog bites. Ophthal Plast Reconstr Surg. 1987;3(4):231-5. [PubMed: 3154600].

10. Erickson BP, Cavuoto K, Rachitskaya A. Zone 3 ruptured globe from a dog bite. J AAPOS. 2015;19(1):89-90. doi: 10.1016/j.jaapos.2014.09.011. [PubMed: 25727600].

11. Prendes MA, Jian-Amadi A, Chang SH, Shaftel SS. Ocular Trauma From Dog Bites:Characterization, Associations, and Treatment Patterns at a Regional Level I Trauma Center Over 11 Years. Ophthal Plast Reconstr Surg. 2015;32(4):279-83. doi: 10.1097/IOP.0000000000000501.

12. Ugboko VI, Olasoji HO, Ajike SO, Amole AO, Ogundipe OT. Facial injuries caused by animals in northern Nigeria. BrJ Oral Maxillofac Surg. 2002;40(5):433-7. [PubMed: 12379192].

13. Jones NP. Perforating eye injuries caused by dog bites. $J R$ Soc Med. 1990;83(5):332-3. [PubMed: 2380952].

14. Lemperle G, Exner K. [Primary management of fresh bite injuries of the face]. Langenbecks Arch Chir. 1987;372:709-12. [PubMed: 3431292].

15. Seguin P, Beziat JL, Freidel M. [Amputation of the point of the nose in children due to a dog bite. Repair with a Washio flap. Longterm results]. Rev Stomatol Chir Maxillofac. 1986;87(3):153-6. [PubMed: 3464071].

16. Van Geertruyden JP. Earlobe reconstruction with a reverse-flow chondrocutaneous flap. Br J Plast Surg. 2002;55(3):253-5. doi: 10.1054/bjps.2002.3817. [PubMed: 12041982].

17. Steinkogler FJ. Reconstruction of the lower lid. Br J Ophthalmol. 1984;68(7):507-10. [PubMed: 6733076].

18. Patel KG, Sykes JM. Concepts in local flap design and classification. Oper Tech Otolaryngol Head Neck Surg. 2011;22:13-23. doi: 10.1016/j.otot.2010.09.002.

19. Ebrahimi A, Ashayeri M, Rasouli HR. Comparison of Local Flaps and Skin Grafts to Repair Cheek Skin Defects. J Cutan Aesthet Surg. 2015;8(2):92-6. doi: 10.4103/0974-2077.158444. [PubMed: 26157308]. 